\title{
Envisioning the sustainability of the production of short rotation coppice on grassland
}

\author{
Christine Rösch $^{1 *}$, Cisco Aust ${ }^{2}$ and Juliane Jörissen ${ }^{1}$
}

\begin{abstract}
Background: Short rotation coppices (SRC) offer a chance to enhance sustainable biomass production and to enlarge domestic wood resources. On arable land, SRC are less competitive in many regions compared to cropping systems and thus farmers are interested to establish SRC on grassland. This change of land use is discussed controversially because of the associated effects on the carbon-sequestering ecosystem grassland. In this paper, land use changes will be analyzed in reference to sustainability objectives, including aspects of land use competition with food and energy production or the preservation of biodiversity.

Methods: The Integrative Sustainability Concept has been adapted and applied to identify the relevant sustainability objectives using a holistic approach in order to assess the potential for the change in sustainable land use towards an expanded supply of lignocellulose-based bioenergy.

Results: A set of sustainability criteria with a special focus on the change in land use from grassland to SRC has been developed and discussed. For selected criteria, adequate sustainability indicators have been chosen and applied to a case study of the state of Baden-Wuerttemberg in Germany. The indicators have been implemented by performing a spatial differentiated bottom-up assessment using GIS-based data. The results revealed that around $13 \%$ of the grassland could be converted into SRC without harming the considered sustainability criteria.

Conclusions: The exploitation of the assessed potential for the change in sustainable land use from grassland to SRC could contribute to decentralize renewable energy supply, local employment and income. With regard to the economic values otherwise lost-, it is recommended not to set grassland conservation as an area-wide imperative. Instead strategies to direct the establishment of SRC to the most suitable areas and technologies should be developed realizing that land use transformation will be performed in a minimal invasive way to ensure compliance with the environment and climate protection.
\end{abstract}

Keywords: Sustainability, Land use change, Grassland, Short rotation coppice, Bioenergy, Environment

\section{Background}

The European Union (EU) has acknowledged the ecological functions of grassland and introduced measures within the Common Agricultural Policy (CAP) for its protection against conversion into arable land as well as for preserving or enhancing its ecological quality. Cross compliance, linking the full receipt of direct payments for farmers to compliance with environmental and further standards, explicitly addresses the protection of grassland (Regulation (EC) nos. 796/2004 and 73/2009). EU member states must ensure that at the national scale,

\footnotetext{
* Correspondence: christine.roesch@kit.edu

${ }^{1}$ Institute for Technology Assessment and Systems Analysis (ITAS), Karlsruhe Institute of Technology (KIT), P.O. Box 3640, 76021 Karlsruhe, Germany Full list of author information is available at the end of the article
}

the ratio of the land under permanent grassland in relation to the total agricultural area may not decrease by more than $10 \%$ compared to the year 2003. Germany implemented precautionary measures before the $10 \%$ threshold has been reached. A need for authorization to convert grassland to arable land is required if the 5\% level is exceeded.

Resulting from the introduction of cross compliance in Germany, the ratio of permanent grassland is declining. By 2010, the 5\% threshold was exceeded in four federal states. The federal states level is the level on which this ratio is calculated in Germany [1]. As a result, for any further conversion of permanent grassland, authorization has to be sought and as a rule, grassland

\section{实}


has to be created elsewhere as compensation. More incentives for grassland are provided at the regional level in order to preserve certain management practices of extensive grassland. For less favoured areas, natural handicap payments are given to support grassland management even under adverse conditions. However, these incentives could not stop the further decline of grassland either.

The main driving forces for the decrease of grassland are not only the continuously shrinking cattle stock being the primary user of grassland [2], but also the German Renewable Energies Act which makes the production of maize as a feedstock for biogas plants profitable. Around $53 \%$ of the permanent grassland that has been converted to arable land is being used to cultivate maize [1]. This land use change can induce negative impacts on the environment because grassland provides several important ecological benefits including carbon storage, protection of soil from erosion, ground water formation, and habitat function. Besides, grassland is forming an essential part of the cultural landscapes serving as a basis for nature-related recreation and tourism.

Since July 2011, the federal state of Baden-Wuerttemberg has prohibited the conversion of grassland by law. In the $\mathrm{EU}$, the absolute maintenance of grassland is under discussion and could become one of the pillars of the projected ecologization of the CAP. Such a regulation would prevent any type of changes in grassland use regardless of their impacts. The justifications for such an absolute prohibition of grassland conversion are the multifunctional environmental benefits of grassland. Thereby the focus is on the functions of grassland as a host of endangered wildlife and plants and as a protector of huge carbon deposits which would otherwise be released as greenhouse gases. In BadenWuerttemberg, around $6 \%$ of the permanent grassland covering 532,000 ha or $38 \%$ of the agricultural used land is extensively managed, e.g. as meadow with scattered fruit trees [3]. This area is of great importance for the preservation of biodiversity. Part of the remaining grassland could be used for alternative biomass production. Permanent crops such as Miscanthus or fast growing trees have higher biomass yields compared to grassland, and the biomass has a higher amount of lignocellulose and a lower amount of nutrients that makes them more advantageous for renewable energy supply.

Against this background, it is the aim of this paper to evaluate the changes in land use from grassland to short rotation coppice (SRC) by reference to the Integrative Sustainability Concept. The focus is on SRC because fastgrowing trees could contribute to the national wood resources and help to release the pressure on forests to become more productive in satisfying the growing demand for wood as an energy carrier which has been doubled in Germany within the last 5 years. The reserves to expand the use of wood in public forests without impairing sustainable and multifunctional forestry are limited due to ecological constraints. In small-size private forests with still higher wood reserves, structural problems prevent the mobilization of residual forest wood [4].

In Germany and also in other European countries, the cultivation of SRC has been intensively discussed and explored. According to the EU premium rights and to the German Federal Forest Act, SRC set up on agricultural land do not fall within the definition of forest. Hence, SRC maintain the legal status of agricultural areas as long as the rotation period is not longer than 20 years. Meanwhile, in Germany, around 4,000 ha of SRC have been established mainly for research and demonstration purposes. Energy scenarios are assuming that large agricultural areas are usable for SRC [5,6]. The European Environment Agency estimates that between 824,000 ha today and around 3.4 million ha in 2030 could be available for biomass crop production in the EU-15 (Austria, Belgium, Denmark, Finland, France, Germany, Greece, Ireland, Italy, Luxembourg, the Netherlands, Portugal, Spain, Sweden and the United Kingdom). More than half of which is available as former grassland [7].

\section{Methods}

The Integrative Sustainability Concept [8] provides a theoretically well-founded approach to operationalize the Leitbild of sustainable development and an operable analytical tool for sustainability analyses. It has been applied so far successfully in various research projects on the global, national and regional levels [9]. The substantial minimum requirements of the Integrated Sustainability Concept (see Table 1) were chosen to identify relevant criteria for the assessment of the change in land use from grassland to SRC.

The adaptation of the Integrative Sustainability Concept to the context of land use changes requires the identification of the relevant objectives as well as the selection of appropriate sustainability goals and indicators to measure the progress in reaching these goals. The sustainability objectives which have been considered to be most relevant in the context of land use change to SRC are listed in Table 2.

The conversion of grassland to SRC affects the objective to secure the supply of food as a basic human need because grassland is the main feedstock for milk and cattle meat production. The ongoing grassland conversion and expanding urbanization contribute to the continuous loss of this food production resource. At the same time, transforming grassland to high-yielding SRC production sites is detrimental to food supply. There is disagreement about how significant the 'food versus fuel' 
Table 1 Objectives of the integrative sustainability concept [8]

\begin{tabular}{lll}
\hline Securing mankind's existence & Upholding society's productive potential & $\begin{array}{l}\text { Keeping options for development and } \\
\text { action open }\end{array}$ \\
\hline Protection of human health & Sustainable use of renewable resources & $\begin{array}{l}\text { Equal access to education, information, and an } \\
\text { occupation }\end{array}$ \\
\hline Securing the satisfaction of basic needs & Sustainable use of non-renewable resources & $\begin{array}{l}\text { Participation in societal decision-making } \\
\text { processes }\end{array}$ \\
\hline Autonomous self support & Sustainable use of the environment as a sink & $\begin{array}{l}\text { Conservation of the cultural heritage and of } \\
\text { cultural diversity }\end{array}$ \\
$\begin{array}{l}\text { Just distribution of chances for using natural } \\
\text { resources }\end{array}$ & Avoidance of unacceptable technical risks & Conservation of nature's cultural functions \\
\hline $\begin{array}{l}\text { Compensation of extreme differences in } \\
\text { income and wealth }\end{array}$ & $\begin{array}{l}\text { Sustainable development of real, human, and } \\
\text { knowledge capital }\end{array}$ & Conservation of social resources \\
\hline
\end{tabular}

debate is, but consensus exists that biomass use for food should be prior to energy production.

Farmers provide a strong economic and social base for rural development. Diversification of income sources such as the increasing involvement of farmers in renewable energy production (e.g. biogas plants) helps to ensure the autonomous self support of people working in the agricultural sector.

Agriculture has strong impacts on the use of the renewable resources soil, water and biodiversity. For example, agricultural practices are the single greatest contributor to the increase in soil erosion rates. Increasing production of renewable energy from biomass contributes to the substitution of fossil fuels and the avoidance of carbon emissions and climate change.

Agricultural activities rely on different types of capital including the real (natural) capital - the soil resource, water from rainfall or other sources, the air, animals used for their labour and as a source of manure, the surrounding natural vegetation; the human capital -

Table 2 Sustainability objectives for changes in grassland use

\begin{tabular}{ll}
\hline Sustainability objectives & Explanation \\
\hline $\begin{array}{l}\text { Securing the satisfaction of basic } \\
\text { human needs }\end{array}$ & $\begin{array}{l}\text { Affordable provision with basic } \\
\text { supplies such as food and energy } \\
\text { and prevention of competition } \\
\text { between the use of commodities }\end{array}$ \\
\hline Autonomous self support & $\begin{array}{l}\text { Adequate and stable economic } \\
\text { existence by income-producing } \\
\text { employment through agricultural } \\
\text { land use }\end{array}$ \\
\hline $\begin{array}{l}\text { Sustainable use of renewable } \\
\text { resources }\end{array}$ & $\begin{array}{l}\text { Warranty of the efficiency, reliability } \\
\text { and replacement of renewable } \\
\text { resources }\end{array}$ \\
\hline $\begin{array}{l}\text { Sustainable use of non- } \\
\text { renewable resources }\end{array}$ & $\begin{array}{l}\text { Substitution of non-renewable fossil } \\
\text { energy carriers with bioenergy }\end{array}$ \\
\hline $\begin{array}{l}\text { Sustainable development of real, } \\
\text { human, and knowledge capital }\end{array}$ & $\begin{array}{l}\text { Priority for feedstock production to } \\
\text { operate existing food processing and } \\
\text { bioenergy plants }\end{array}$ \\
\hline $\begin{array}{l}\text { Conservation of nature's cultural } \\
\text { functions }\end{array}$ & $\begin{array}{l}\text { Preservation of cultural and natural } \\
\text { landscapes of particular characteristic } \\
\text { and beauty }\end{array}$ \\
\hline
\end{tabular}

humans who supply labour, not only physical labour but also intellectual input for planning production strategies; the social capital - systems providing labour and marketing support as well as information related to agriculture and health services; the financial capital - markets for purchase and sale of goods and a credit system supplying funds to all levels of agricultural workers; and human-made capital - implements needed for agriculture, roads and means of transport and factories for processing of farm produce. At every level, an agricultural system depends 'on the value of services flowing from the total stock of' these five types of capital. (Table 2).

The choice of objectives is accomplished by scientific expertise and based on reflections with regard to criteria relevance, diversity, comprehensibility and data availability. Consequently, the set of criteria is neither complete nor perfectly consistent with the initial proposition nor fully developed in terms of the complexities of systemic interactions and cross impacts. The preliminary character of the set of sustainability criteria proposed in this paper is amplified by the fact that an agreement has to be brought about regarding the selection of sustainability criteria preferably via negotiations within society and politics. Such a transdisciplinary approach, however, would have gone beyond the scope of the research described in this paper. In the following section, the characteristic aspects of the sustainability objectives listed in Table 2 will be discussed.

\section{Satisfaction of basic human needs}

The ongoing increase in agricultural yield has first led to overproduction of food in Germany and the EU and then to the implementation of set-aside programmes to restrict food production. The subsequent set-aside areas have been unlocked from the production ban for the purpose to grow crops for material or energy supply. In Germany, now more than 2.15 million ha or $18 \%$ of the agricultural land are used for the production of renewable resources. Growth of crop yields has slowed down considerably, and fears are expressed that the trend may not reverse [10]. The question is whether the lower 
growth potential is sufficient to meet the increased requirements. Climate change, furthermore, looms largely as a risk that would negatively affect the production potentials of agricultural resources.

The increased request for agricultural land by the concurrent production of food and energy is visible in rising prices for the purchase and lease of agricultural land respectively in the neighbourhood of biogas plants [11]. The price lift for arable land is much higher than for grassland, indicating the restricted land use options for grassland compared to arable land. The boosters of the advancing demand for land in Germany are the economic incentives given by energy politics in order to reach the ambitious renewable energy goals.

Food production should be the prior land use because renewable energy can be supplied by other types of renewable resources, such as wind, sun, water or geothermal power. The human need for food however can exclusively be covered by biomass produced on land and water-based production systems. Concerning this ethical aspect of land use, grassland needed for livestock grazing respectively for cattle farming or feeding other ruminants, such as sheep, should not be used for establishing non-food crops such as SRC.

The question though is how much grassland is needed to accomplish food supply today and in the future in a world based on the division of labour and resource use. In Germany, grassland is characterized by a long-term decline without visible impact on the food supply. Between 1990 and 2006, the area of permanent grassland in Germany declined at an annual rate of $0.8 \%$, while arable land only decreased at a rate of $0.05 \%$ per year [1]. The overall loss of farmland due to urbanization seems to have occurred mainly at the expense of grassland [12]. This development is the result of the decrease in dairy cows due to political and economic constraints (i.e. the imposition of milk quotas) and the progress in breeding and milk production which have subjected milk production to significant structural changes for many years [13]. The average annual milk production per cow in Germany has increased from $4,710 \mathrm{~kg}$ in 1990 to $7,080 \mathrm{~kg}$ in 2010 [14]. Similarly, there has been a reduction in the number of beef cattle following the Bovine spongiform encephalopathy crisis in the late 1990s and the reduction and eventual removal of specific beef production incentives. As progress in breeding and dairy cow milk production will continue, a further decline in the demand of grassland can be expected.

Besides progress in breeding and milk production, the demand of grassland is influenced by the spatial allocation of the dairy and cattle stock and also by the intensity of dairy cow milk production and feed production on grassland and arable land. These factors are strongly dependent on economics, which in turn is influenced by agricultural policies and incentives. The objective of the German Sustainability Strategy to increase the share of extensive organic farming from $5.9 \%$ in 2010 to $20 \%$ will increase the demand of grassland for roughage production [15].

Since grassland is just one source of animal feed, its competiveness as compared to maize is crucial for its application [13]. Until the 1970s, grassland, lucerne and clover had been the main feeding base for cattle farming. Today, these traditional forage plants have been replaced continuously by maize. This is due to the area-specific higher yield of maize in contrast to grassland. This configuration will not be changed in the future as long as the spread of pests such as the corn rootworm will not limit maize production.

The conclusion is that grassland can be replaced by crops with higher yields per hectare such as maize. However, importing feed like soy bean from Latin American countries instead of using domestic grassland for the supply of animal feed raises ethical issues.

\section{Autonomous self support}

In common with most high-income countries, the agriculture's contribution to the German gross domestic product and employment is low, although agriculture is the largest type of land use accounting for about 52\% of the total area. The regional importance of the sector and its associated food and farming industries varies considerably. The job and income opportunities associated with agricultural land use are strongly influenced by government interventions in agricultural markets. They are likely to be the most critical drivers of agricultural land use change with significant influence on the landscape.

The German agricultural policy has primarily been determined by the European CAP covering the key agricultural commodities. The CAP was devised to increase agricultural productivity, stabilize markets and assure the availability of reasonably priced food, and to ensure a fair standard of living for all those involved in farming. These objectives were largely met by the support of internal prices and incomes, through direct market intervention, and border protection through tariffs and levies on food imports. Export subsidies were paid to offload otherwise uncompetitive EU surplus production onto world markets. The policy was successful in terms of increasing domestic food production, to the extent that the EU became the second largest exporter of food in the world. However, this policy resulted in higher consumer food prices within the EU and increasing of tax burdens on EU citizens. Its legitimacy as a means of supporting farm and rural incomes was eventually challenged by food exporting nations and the World Trade Organization.

The drive for food production between 1940 and 1984 had led to substantial areas of permanent pasture being 
ploughed and drained, usually with grant support. By 1984, surplus milk production led to the introduction of marketable milk quotas. Eight years later, in 1992, the MacSharry reforms of the CAP led to constraints being placed on the beef and sheep sector, with compensation payments which were subject to regional ceilings and maximum stocking rates. At the same time, compensation payments in the arable crop sector required the compulsory withdrawal (or setting-aside) of up to $10 \%$ of arable land from production.

The negative environmental effects of intensive farming and land use change including loss of habitats and wildlife, soil erosion and water pollution have lead to a change in agricultural politics. Today, payment for farmers is not linked anymore to a particular type of production, but does require 'cross-compliance', an adherence to EU environmental, food safety, animal welfare standards and regulations, and the need to keep farmland in good agricultural and environmental condition. This is defined at a national level and includes the maintenance of grassland.

For grassland different incentives are available on the national and regional level, but for SRC, the payments are limited. With respect to the on-farm economic competitiveness of SRC toward the classical use of agricultural land under German conditions, it might be profitable to establish SRC, but today this is mainly not the case [15-17]. The establishment of SRC is hampered by traditionalistic behaviour and risk aversion, too. SRC involve investment costs that are at least partly sunk or irreversible, and they are changing the farm's revenues and expenditures over a long period of time. Farmers would go for $\mathrm{SRC}$ if the present value of the investment returns exceeds the investment costs considerably or additional and longlasting area payments for SRC are provided by policy and society [18]. Farmers do not want to allocate their land for long periods of time and rather prefer great flexibility in their planting decisions in order to rapidly react to changes in prices for agricultural commodities.

\section{Sustainable use of renewable resources}

The EU has acknowledged the various ecological functions of grassland for the preservation of renewable resources and its benefits in terms of soil, water and biodiversity protection. Hence, the EU has introduced measures within the CAP for its protection against conversion into arable land as well as for preserving or enhancing its ecological quality. Extensively cultivated grassland belongs to the most species-rich land use types in Europe [19] and, after being destroyed, may only recover very slowly [20]. The conversion of this type of grassland could lead to a loss of biodiversity and should thus be excluded from changes in land use.
In recent times, grassland has received considerable attention for its carbon sink capacity and high carbon stock compared to arable land [21]. In particular, grassland on organic soils store very high amounts of carbon [22,23]. The conversion from permanent grassland to arable land is accompanied by a massive boost of mineralization due to decomposition of soil organic matter and consequently rising greenhouse gas (GHG) emissions as well as higher nutrient runoff and leaching to surface and ground water. Converted grassland may lose about $50 \%$ or more of its original soil carbon under arable management [24]. In the case of temperate grasslands which contain in average around $330 \mathrm{mg}$ of carbon per hectare, this is a tremendous release of GHG [25]. In contrast, a conversion of arable land to grassland results in increased carbon storage, however, at a much slower pace and rarely reaching the former level. Compared to annual agricultural crops such as rapeseed or maize, fast-growing trees have significantly lower negative impacts on the environment [24,26-29]. This is related to the extensive form of cultivation which can lead to an increase of carbon and humus in the soil and their low demand for nutrients and pesticides [30,31]. Established SRC have a high economic threshold to pest damage and can be managed with few pesticide applications. Tolerating the presence of certain insects and other plants is, in turn, cited as the main reason why SRC, if appropriately located, has the potential to increase biodiversity in many farmland situations [32].

The establishment of SRC on grassland is less valuable for the protection of resources and the environment than on arable land. The deterioration of the ecological functions of grassland can be reduced by the non-plough tillage, minimal invasive establishment of SRC and the abandonment of returning the SRC plantation into grassland or arable land [33]. Hence, SRC can contribute to both the buildup of humus and improvement of the soil quality, in particular, on soils with low carbon stocks [34]. This assumption is eligible because fast-growing trees in contrast to annual non-woody energy crops do not require good carbon-rich soils to achieve economically promising yields. They can also be produced on marginal agricultural sites with a low natural productivity, like sandy or stony soils; if the average temperature enables long vegetation periods, the requirements by the species are respected and water supply is guaranteed due to access to groundwater resources or sufficient precipitation [30].

SRC can also be beneficial for the protection of biodiversity within sparsely wooded pastoral landscapes where they could provide wooded stepping stones for birds of wooded habitats $[35,36]$ and create networks of biotopes and enhance biodiversity [37,38]. Positive effects for biodiversity can also be expected when SRC are established in riparian buffer stripes to ensure that the regulations of distance regarding the application of fertilizer and pesticides 
will be respected [30] and in emission stripes along transportation routes to shield the fields behind against pollutants [31]. In water regulation areas, SRC can contribute to retard peak flows, decrease surface runoff and utilize the soil as a buffer [28,30]. Against this background, it can be concluded that even on grassland the establishment of SRC can be beneficial for the preservation of renewable resources and the environment. The areas where this is true and which are not reaching a certain critical value of natural protection and the preservation of ecosystem services [27,28], should be identified and made available for establishing SRC. The measure for planting and operating SRC has to be conducted environmentally sound and needs to fit into the general principles for saving both natural and cultural landscape [27-29,39].

\section{Sustainable use of non-renewable resources}

Energy and carbon analysis of different power generation processes based on SRC demonstrated that these processes use comparatively less fossil fuel and avoid more greenhouse gas emission per unit of produced energy than conventional high-input bioenergy crops [40]. The energy ratio of SRC is within the range of 22 and 28 depending on both the assumptions made with regard to the production and transformation processes and on the fact which energy consumptions along the process chain are included [41,42]. SRC are well positioned among the best energy crops and can contribute to increase the share of bioenergy compared to the energetic use of grassland and thus the amount of fossil energy carriers that can be substituted.

\section{Sustainable development of real, human and knowledge capital}

In times of financial crises, the sustainable use of capital is of increasing importance for a sustainable development. Investments in bioenergy plants, such as biogas plants, which have been made in the last years based on the fixed feed-in tariffs specified by the German Renewable Energy Sources Act (EEG) could be endangered by rising prices for biomass feedstock due to an increasing competition for land use. Among the means of using grassland biomass, biogas production currently is the most common practice in Germany. Surveys of agricultural biogas plants in Germany show that grass silage is used as a feedstock in more than $50 \%$ of the biogas plants and is the second most frequent crop feedstock after maize silage [43]. Particularly, in regions with high percentages of grassland, the relevance of grass silage as a biogas feedstock could be quite high. To deal with the capital as a limited financial resource in a sustainable way, it is defined in this paper that grassland used to produce grass silage for already existing or planned biogas plants should not be taken into consideration for the establishment of SRC.

\section{Conservation of nature's cultural functions}

The functions of nature are mainly associated with its life-support and ecological services. The important and irreplaceable cultural functions which are performed by natural environment are rarely investigated. This is due to the challenge to determine indicators and values for these sociocultural functions and their values for the health and well-being of human societies. The importance of the information functions (health, recreation, amenity, education, heritage, etc.) for the quality and sustainability of human life, however, is undisputed. Despite their immaterial and often intangible nature, these functions provide many socioeconomic benefits which might be assessed through both qualitative and quantitative evaluation methodologies. Depending on the spatial embedding and the design of SRC plantation, they can either enrich or depreciate the cultural landscape. The impact on the landscape largely depends on the suitability of the proposed location and on the current character and sensitivity of the landscape. In general terms, lowland landscapes with high levels of tree and woodland cover and arable or mixed farming are most suitable for SRC. It is also important to remember that cropping is heavily mechanized and requires land suitable for mechanical operations: This excludes steep or boggy ground.

The impact of SRC on the landscape will increase if whole farms or substantial parts of farms are planted. There is a risk that the diversity of the landscape will be reduced and that it will appear saturated [44]. It is important to build diversity into large-scale planting by varying age structure and introducing open space so that the crop is subdivided at a scale that suits the particular landscape type. Some landscapes, such as parkland and historically designed landscapes may be unsuitable for the introduction of SRC on any significant scale. In areas well used by the public such as near public rights of way, access routes and roadsides, a more detailed design may be necessary to respect cultural functions.

\section{Indicators for sustainable grassland use change}

The sustainability targets can be operationalized by the application of a readily comprehensible set of sustainability indicators. This way, the quality of the dialogue about sustainable land use change from grassland to SRC can be enhanced. The selection of suitable indicators is based on the following criteria: relevance, directional safety, availability of data, comprehensibility, and practicability. The indicators chosen to identify potential grassland areas which could be used for a sustainable establishment of SRC are listed in Table 3.

The analysis of sustainability indicators in this paper is focusing on the most important indicators regarding their relevance to illustrate the sustainability objectives which are strongly affected by the conversion of grassland to 
Table 3 Sustainability indicators for identifying grassland suitable for SRC

\begin{tabular}{ll}
\hline Sustainability objective & Sustainability indicator \\
\hline $\begin{array}{l}\text { Securing the satisfaction of basic } \\
\text { human needs }\end{array}$ & $\begin{array}{l}\text { Grassland no longer needed for } \\
\text { animal feed production }\end{array}$ \\
\hline $\begin{array}{l}\text { Sustainable use of renewable } \\
\text { resources }\end{array}$ & $\begin{array}{l}\text { Grassland with suitable natural } \\
\text { conditions with regard to } \\
\text { temperature and water availability } \\
\text { for fast growing trees }\end{array}$ \\
& $\begin{array}{l}\text { Grassland with no particular function } \\
\text { for the protection of biodiversity or } \\
\text { ground water }\end{array}$ \\
\hline $\begin{array}{l}\text { Sustainable development of real, } \\
\text { human, and knowledge capital }\end{array}$ & $\begin{array}{l}\text { Grassland without feedstock } \\
\text { functions for biogas plants }\end{array}$ \\
\hline Autonomous self support & $\begin{array}{l}\text { Employment and income by } \\
\text { grassland use }\end{array}$ \\
\hline
\end{tabular}

SRC and considering the availability of data. In the following, these indicators will be applied in the state of BadenWuerttemberg. Besides their purpose for sustainability assessment, they can be used to enhance communication and discussion in society and politics on options for sustainable land use changes. Moreover, they can contribute to provide opportunities for creativity in planning of how to achieve sustainable development and support decisionmakers.

\section{Results}

As a case of application of the selected sustainability indicators the federal state of Baden-Wuerttemberg in Germany has been chosen due to its still high percentage of grassland and the fact that its cattle stock is continuously decreasing. The pattern of grassland use is spatially diverse because of the various natural conditions influenced by different combinations of climate, soils and topography. Major grassland areas can be found in the region of the Black Forest and the Swabian Alb where agricultural land use is difficult due to sparse soils, slopes, temperature and high precipitation.

\section{Grassland suitable for SRC}

Suitable temperature levels and the sufficient availability of water are crucial cultivation factors, especially for poplar and willow grown as SRC $[45,46]$. The water availability can be described by the relief-dependent (influenced by the exposition, slope and relief position) climatic water balance within the period from May to October and the available water capacity in the upper $1 \mathrm{~m}$ of the ground. On 62 polar and willow plantations in south-west Germany and in the northern part of France, the water availability in millimetre and the yields in tons $\mathrm{dm}_{\mathrm{dm}}$ after the first three-year rotation were measured. On the basis of this data, a correlation between the water availability and the achievable yields could be derived and expressed in an equation [47]. The water availability was classified in five water availability stages $(<0,0$ to 100,100 to 200,200 to 300 and $>300 \mathrm{~mm}$ ) to better visualize the natural SRC cultivation potential in maps. These classes represent the suitability of a site for the cultivation of poplar or willow grown as SRC. The classes are sorted in ascending order from $<0$ to $>300 \mathrm{~mm}$ in these categories: excluded, unfavourable, medium, favourable and very favourable. The achievable yields on wet and waterlogged sites were also measured and classified as favourable and unfavourable by a mean annual temperature of more than $8^{\circ} \mathrm{C}$. To consider the influence of the temperature on the growth of SRC, the mean annual temperature was classified in three classes: $<6.5^{\circ} \mathrm{C}, 6.5$ to $8.0^{\circ} \mathrm{C}$, and $>8.0^{\circ} \mathrm{C}$; and the SRC site classes were downgraded according to the temperature class (see Table 4).

Since average temperature and water availability have a strong influence on the land use efficiency and economic performance of SRC, these criteria have particularly been chosen to identify land which is suitable for the establishment of SRC in the research region BadenWuerttemberg. In applying these criteria, it can be concluded that around $12 \%(65,000 \mathrm{ha})$ of the grassland in Baden-Wuerttemberg shows very favourable and around $30 \%(160,000$ ha) favourable conditions for the cultivation of SRC. In total, over $40 \%$ of the grassland can be rated as suitable for fast-growing poplars and willows (see Figure 1).

The percentage of suitable land for poplar and willow SRC within the respective municipalities is considerably high in the south-east of Baden-Wuerttemberg (see Figure 1). Also, parts of the north-eastern mountain regions and the area between the Black Forest and the Upper Rhine Valley possess considerable land potentials.

\section{Grassland without feeding functions}

In Baden-Wuerttemberg, the number of cattle has decreased from around 1.9 million cattle in 1970 to around 1 million cattle in 2010. In the same period, the number of dairy cows has declined from 750,000 to 350,000. Compared to the German average in annual milk production per cow of around 7,080 kg, the average milk in Baden-Wuerttemberg is significantly lower at $6,579 \mathrm{~kg}$ [14]. Thus a further decline in the number of dairy cows can be expected due to progress in milk production and structural changes [2]. This decline is associated with a release of grassland not needed anymore for the production of cattle feed. Part of this so-called surplus grassland has been converted in the last years to arable land in order to produce maize. Agricultural policies and structural changes have shifted the milk production to regions with favourable natural production conditions. The nationwide trade of milk quota has further decreased the number of dairy cows in Baden-Wuerttemberg. Within 3 years, almost $5 \%$ of the total milk production has 
Table 4 Classification of location suitability for short rotation coppice according to water availability and mean annual temperature

\begin{tabular}{|c|c|c|c|c|c|c|c|}
\hline \multirow{2}{*}{$\begin{array}{l}\varnothing \text { Annual } \\
\text { temperature }\left({ }^{\circ} \mathrm{C}\right)\end{array}$} & \multicolumn{7}{|c|}{ Water availability stages } \\
\hline & $<0 \mathrm{~mm}$ & $0-100 \mathrm{~mm}$ & $100-200 \mathrm{~mm}$ & $200-300 \mathrm{~mm}$ & $>300 \mathrm{~mm}$ & Wet & Water logged \\
\hline$<6.5$ & Excluded & Excluded & Excluded & Excluded & Excluded & Excluded & Excluded \\
\hline $6.5-8.0$ & Excluded & Excluded & Unfavourable & Medium & Favourable & Medium & Excluded \\
\hline$>8.0$ & Excluded & Unfavourable & Medium & Favourable & Very favourable & Favourable & Unfavourable \\
\hline
\end{tabular}

been translocated to the other states [48]. This correlates with a dismount of 15,000 cows or a surplus area of 7,000 ha grassland.

For the calculation of the surplus grassland, a method was developed to assess and allocate the surplus grassland on the basis of different statistical data on land use, livestock and agricultural yields in Baden-Württemberg as described in [49]. Further data needed for the calculation such as the energy content of grass silages were raised by a special two-step survey among the local agricultural offices. First, based on these data, the roughage demand of cattle, horses and sheep was calculated. Then the production volume of the different types of grassland (meadows, pasture) as well as other fodder crops was calculated in relation to the average yield and energy content on district level. Finally, the production volume was balanced with the estimated roughage demand of the livestock. For more information, see [49]. According to this method for calculating the amount of surplus grassland, it has been assessed that in Baden-

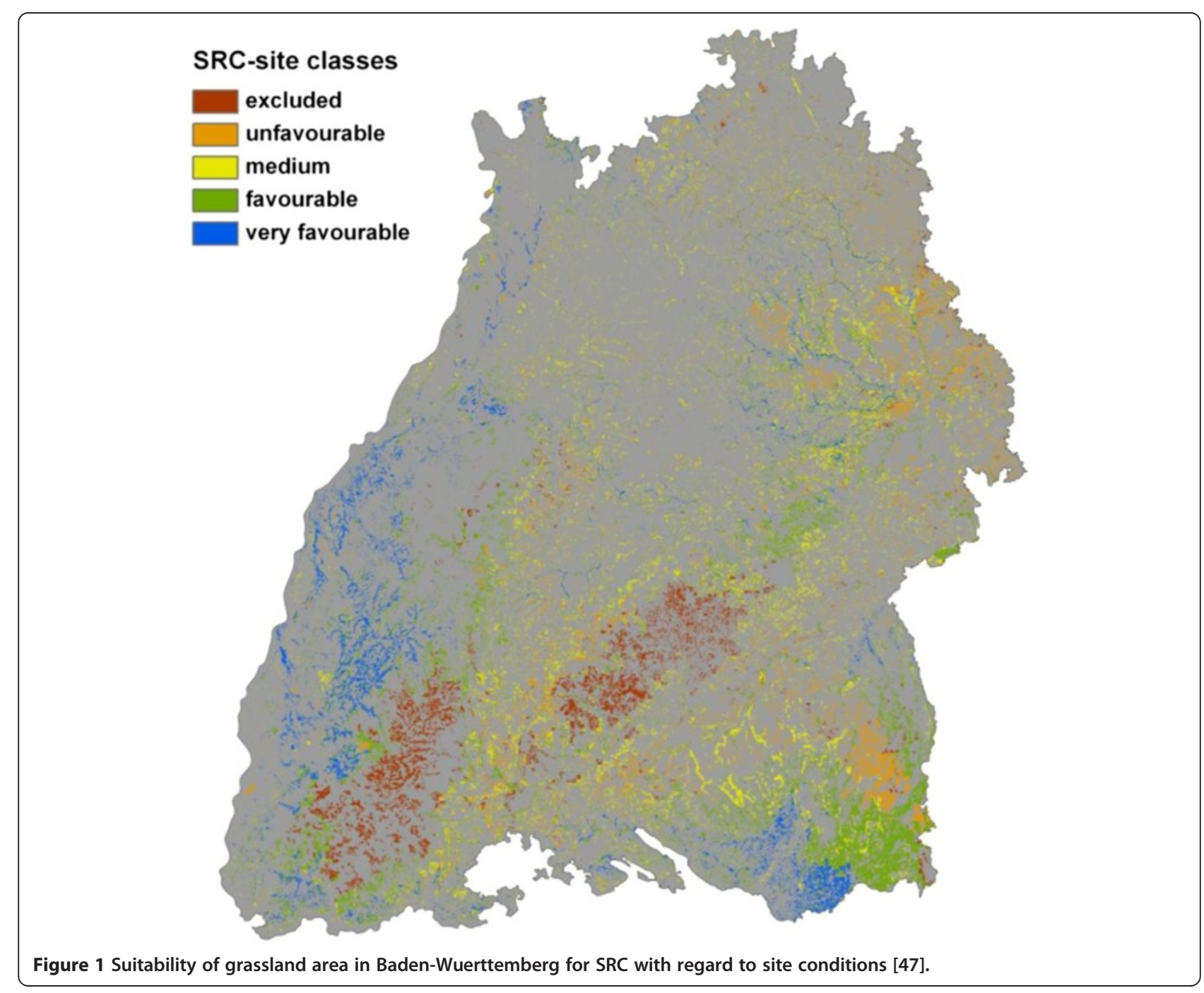


Wuerttemberg, currently around 100,000 ha of the permanent grassland are not needed anymore for roughage production. The spatial distribution of this surplus grassland is quite different (see Figure 2). The main part of this surplus grassland which could be used for establishing SRC is located in the region of the Black Forest and the Swabian Alb.

At present, the exploitation of the potential of this grassland for SRC is limited by political frame conditions. Under the EU Cross Compliance Regulations within the Common Agricultural Policy, EU member states are required to ensure that land under permanent pasture is to be maintained. Under present EU legislation, there is a general derogation which allows some decreases provided that they are not significant - defining significant as losses which exceed $10 \%$ of a reference level - to be set by the member states themselves. In Germany, this level was set to $5 \%$ of the reference level to the correlation between grassland and arable land in 2003. In many states of Germany, the limit of $5 \%$ has already been reached. In the research region, only 24,000 ha or $2.38 \%$ of the referring grassland has been converted so far. Thus grassland could still be converted and used for fast-growing trees. However, legislation in Baden-Wuerttemberg has changed. Since December 2011, the conversion of grassland is prohibited mainly to prevent that more grassland is turned to maize fields for biogas plants. The establishment of SRC on grassland into SRC plantations is also generally excluded by law [50].

\section{Grassland without function for biodiversity or groundwater quality}

Environmental national and regional legislation in the areas of nature conservation and water and soil protection may limit the conversion of grassland in ecologically sensitive locations, such as nature protection areas and drinking water protection areas or flood plains, supporting both national and EU objectives. Grassland possessing a high variety of species is protected

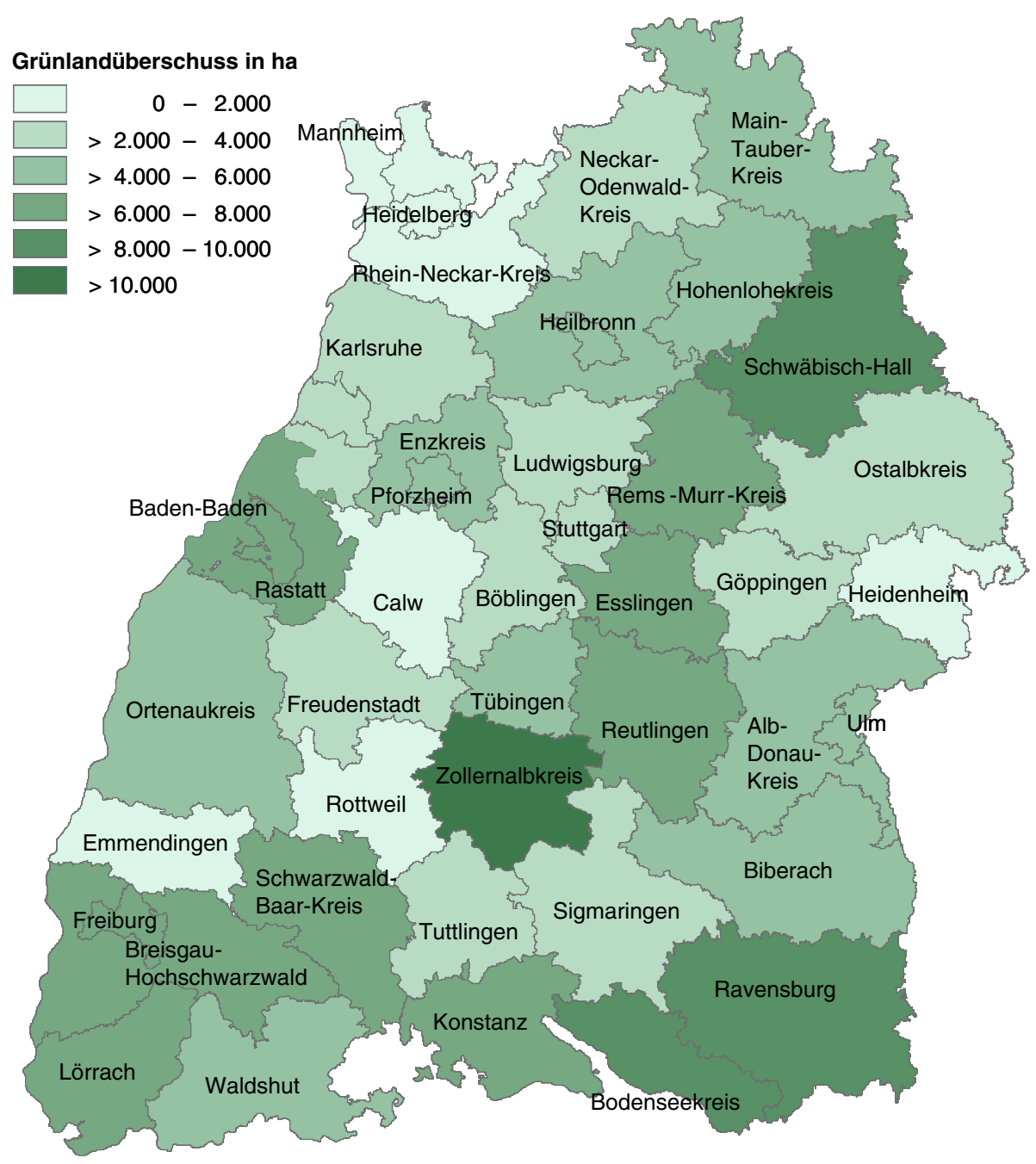

Figure 2 Grassland without a function for cattle feeding in Baden-Wuerttemberg. 
respectively by the FFH-guidelines [51], a specific EU legislation that classifies these areas as 'flora fauna habitats' (NATURA 2000 areas). NATURA 2000 is an ecological network of protected areas in the territory of the European Union based on the Habitats Directive and the Birds Directive, and protects around $18 \%$ of land in the EU countries. Hot spots of distribution for this type of land use in Baden-Wuerttemberg can be found in the mountain areas of the Swabian Alb and, more often, in the Black Forest. Grassland is also protected by the EU guidelines for bird protection, which correspond to $17.3 \%$ of the area of Baden-Wuerttemberg or about 620,000 ha of the NATURA 2000 areas. Amongst them, the proportion of grassland is about 110,000 ha, plus another 30,000 ha of fruit meadows. The protection status of permanent grassland in NATURA 2000 areas, being equivalent to $15.4 \%$ of the German land area, is not clear. In cases where they do not overlap with nature conservation areas, protected biotopes or other areas with defined restrictions on land management, grassland may be converted if a compatibility assessment is conducted featuring that no significant changes in land use are induced. Besides, land use changes are possible in these protection areas as long as this does not result in a significant deterioration or disturbance in relation to the protected habitats or species and it is ensured that habitat conditions would not be affected negatively [1]. This requirement is somewhat vague and apparently leaves some scope for conversion of grassland into arable land, particularly in the case of special protection areas designated under the Birds Directive.

About 25\% of the grassland in Baden-Wuerttemberg is classified as 'extensively cultivated grassland' rich in species. In $8 \%$ of this area, the biodiversity is judged as very high [52] whereas $1 \%$ is classified to be a 'biotope grassland'. The agri-environmental programme of Baden-Wuerttemberg known as 'Marktentlastungs- und Kulturlandschaftsausgleich' or MEKA II [53] acknowledged about 70,000 ha or $12 \%$ of the grassland areas as rich with species. This is just about half of the total extensively cultivated grassland classified this way. High amounts of this species-rich grassland are situated in the Swabian Mountains' districts of Zollernalb and Tuebingen. The preservation of biodiversity is regarded as superior sustainability goal than the production of renewable energy because this objective can be achieved by solar and wind energy too with less impact on biodiversity. Thus, the following categories of grassland are excluded from the establishment of SRC on grassland:

- Areas for the preservation of the diversity of species, officially nominated as Flora Fauna Habitats or Bird Protection Areas (NATURA 2000)

- Natural conservation areas, national parks, core zones of biosphere reserves, protected biotopes according to Section 30 of Federal Nature

Conservation Act or BNatSchG,

- Permanent grassland cultivated extensively.

The high water demand of fast-growing poplars and willows can have an influence on the water availability in groundwater bodies. Thus, land areas with susceptible ground water regimes and crucial functions for water quality and functionality of water bodies are not regarded as suitable locations for sustainable cultivation of fastgrowing trees. Figure 3 illustrates the spatial distribution of the areas for the protection of nature, landscape, biodiversity and water in Baden-Wuerttemberg.

Figure 4 illustrates the areas on which the establishment of SRC is not possible or restricted and the area where fast-growing trees could be planted without impairment of biodiversity and water resources.

\section{Grassland without biogas feedstock functions}

Grassland provides grass silage which is a good feedstock for biogas plants that can easily be stored. Grass silage is applied in over $50 \%$ of the biogas plants and represents the second most important substrate type on a federal level providing $11 \%$ of the whole amount of biomass for biogas plants and allocating $12 \%$ of permanent grassland [43]. In Baden-Wuerttemberg, the average proportion of meadow grass differs between $9 \%$ in large plants $>500 \mathrm{~kW}$ and $15 \%$ in small plants of $150 \mathrm{~kW}$ [54]. The distribution of biogas plants and the proportion of grass used for biogas plants are spatially different as shown in Figure 5. This is not only the influence of the spatial distribution of small and large-scale biogas plants but also due to the relation of grassland to arable land which is quite unequal in the various districts. In the south of the Black Forest (mainly in the districts Breisgau-Hochschwarzwald and Tuttlingen), grassland is the main source of feedstock for biogas production delivering more than a third of the biogas feedstock. In Baden-Wuerttemberg, the installed capacity of biogas plants has continuously increased until 2011 up to 256 MW of electricity. Assuming that in average 11\% of the biogas feedstock supply for these plants derives from grassland, about 27,000 ha of grassland are needed to produce substrate for biogas plants. The increased use of grassland as a biogas feedstock resource could be one way to counter the widely expressed criticism of the significant expansion in maize cultivation for biogas plants. Despite its ecological advantages compared to maize, an enlargement of the share of grass feedstock is not assumed here because permanent grassland is less competitive in many regions compared to cropping systems [55]. The preference for growing silage maize for biogas production is based primarily on its high yields per hectare. In order to facilitate the use of grass, the Renewable 


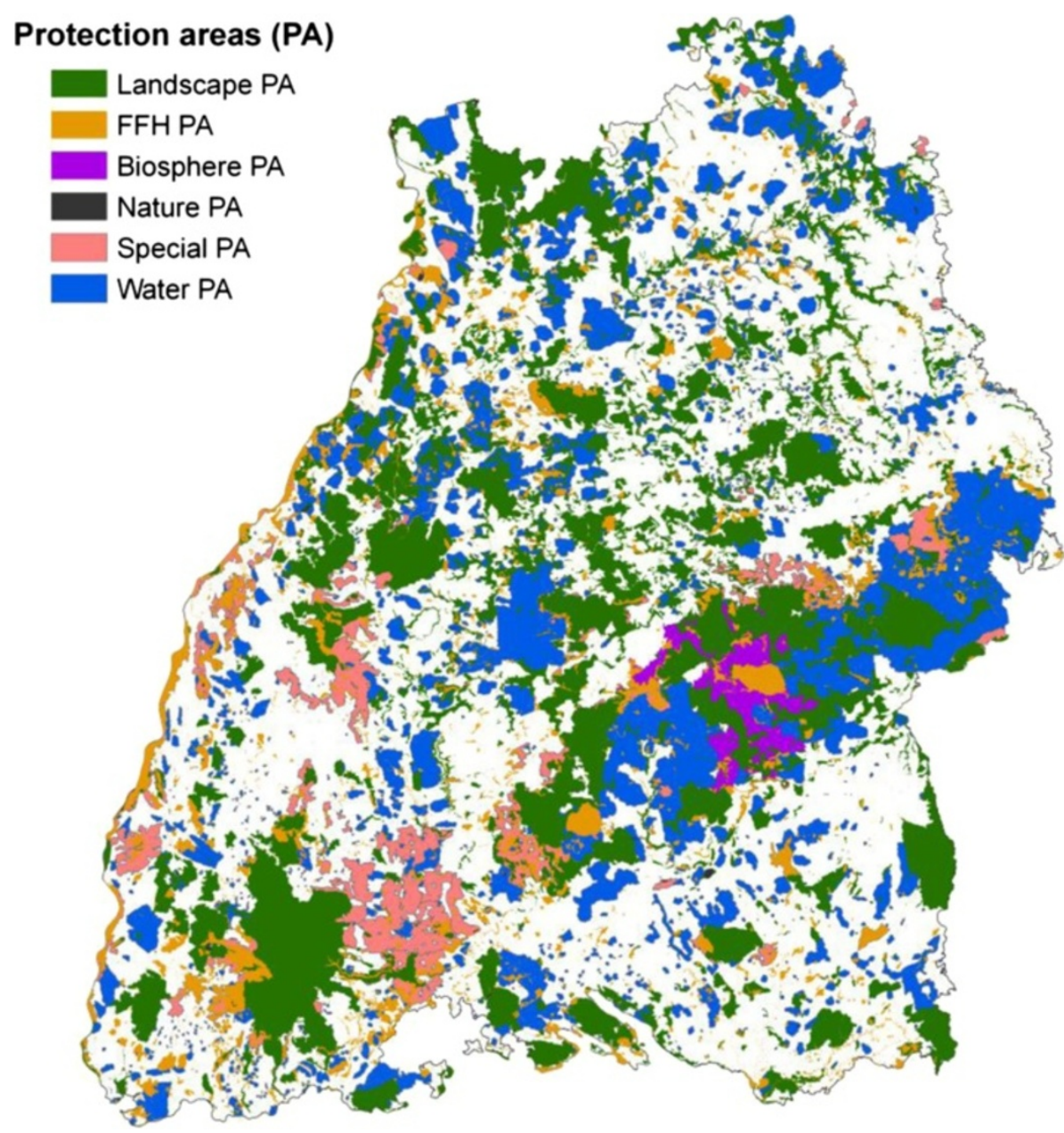

Figure 3 Spatial distribution of the areas for protection of nature, landscape, biodiversity and water in Baden-Wuerttemberg [47].

Energy Act (EEG) 2012 introduces upper substrate limits for maize and cereal grain (ethical discussion) and different raw material payment classes (0, I, II). The intention is to expand the cultivation and use of grass and alternative substrates by providing a higher payment for the feedstocks.

This area of grassland assigned for biogas production is not considered to be disposable for establishing fastgrowing trees in order to avoid feedstock competition. This prioritization is based on the sustainability goal not to jeopardize the sustainable use of real and human capital which has already been invested in local biogas plants and operation. Besides, the total area occupancy caused by biogas plants is already quite high in districts with large amounts of cattle livestock. Thus, negative impacts on the availability of land and land tenures have already been documented for such areas $[56,57]$. Finally, only grassland which is not dedicated to biogas production should be considered for the establishment of SRC.
Employment and income by SRC on grassland

Milk and meat production based on dairy cows and cattle is the main source of employment and income from grassland. In Baden-Wuerttemberg, one quarter of the agricultural production value is generated on grassland [58]. As usual, the spatial distribution of this production value is differentiated. The main production areas are located in regions with favourable natural conditions for milk production such as the Allgaeu, Upper Swabia and the region from the Ostalb to Hohenlohe (see Figure 6). Over $30 \%$ of the total milk production is generated by two districts in the south-eastern part only, Ravensburg $(464,100 \mathrm{t} / \mathrm{a})$ and Biberach $(226,000 \mathrm{t} / \mathrm{a})$. However, also in these districts, grassland which is no longer used for milk production could be used for the establishment of SRC. The land in question is mainly marginal grassland with regard to the practicability for cultivation with large-sized efficient harvest machinery [2]. The establishment of SRC will result in 


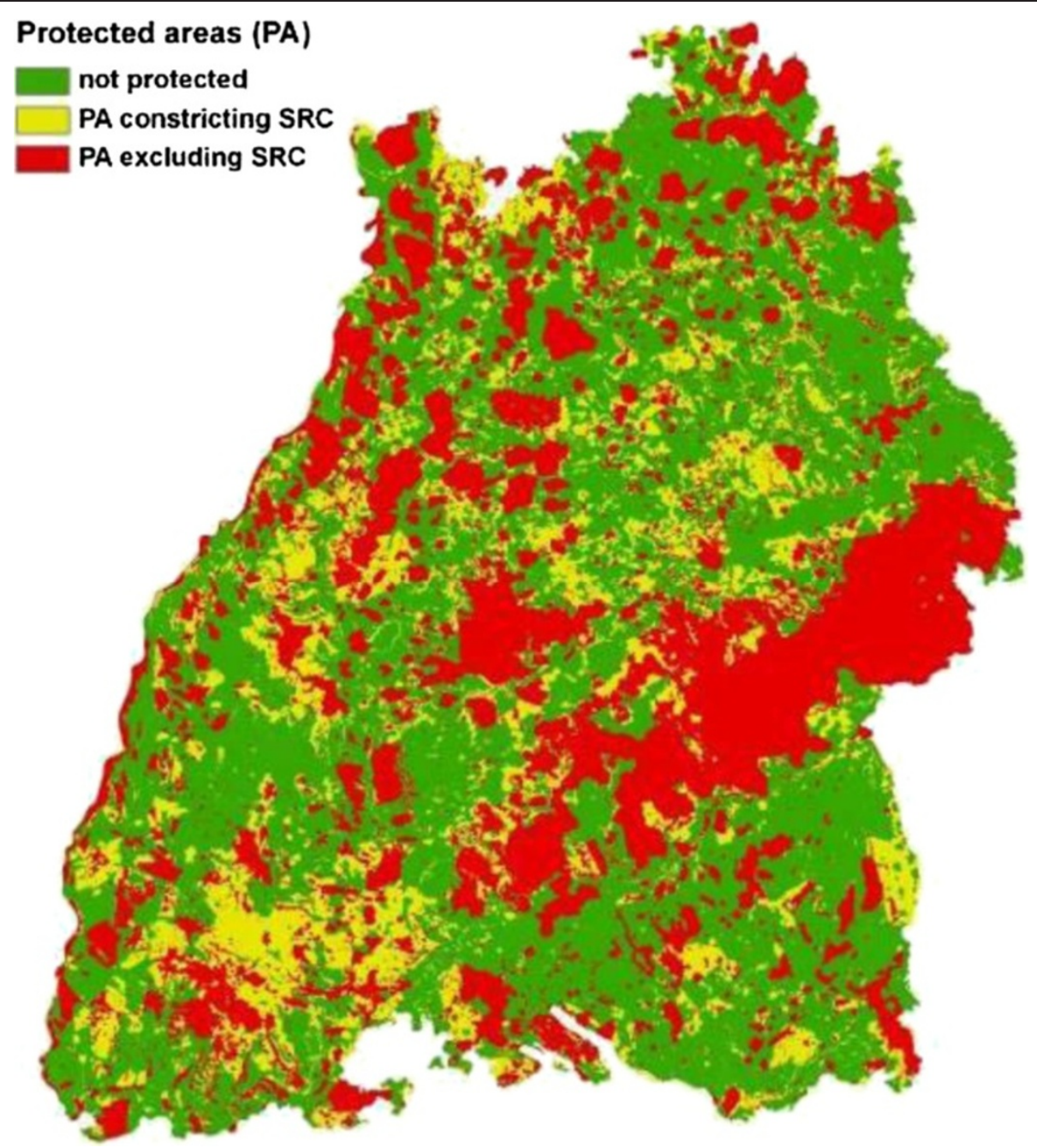

Figure 4 Locations where the cultivation of SRC is restricted due to environmental aspects [47].

a reduction of employment and income compared to grassland which is used as resource for milk and meat production due to afar less labour-intensive production chain. Yet, if SRC are grown on surplus grassland without functioning as dairy and cattle or biogas feedstock, a positive impact on employment and income for the local community can be realized. Hence, from the view of sustainable development, only the grassland area identified in the preceding chapters should be applied for the establishment of SRC.

\section{Grassland suitable for SRC with regard to sustainability}

The results achieved by the application of the previous sustainability criteria exhibit that in the research region, around $13 \%$ or 70,000 ha of grassland are suitable for the establishment of SRC. A main part of this grassland can be found in the south-eastern part of BadenWuerttemberg (see Figure 6).

\section{Discussion}

The sustainability debate on land use change is often narrowed and reduced to the questions of compatibility with environmental and climatic conditions. However, land use change has to be evaluated against a much larger spectrum of sustainability criteria, including aspects of security of supply and economic development of rural areas. The adoption of the Integrative Sustainability Concept to analyse land use change from grassland to SRC has the big advantage that socio-economic and ecological aspects are regarded together and of equal rank. From the 15 principles of the Integrative Sustainability Concept, six principles have been regarded as relevant to describe the impacts of land use change. Aside from the sustainable use of renewable resources, the criteria referring to the satisfaction of basic human needs, the autonomous self support of the population and the development of real, human and knowledge capital have been identified as highly relevant for identifying grassland which could be 


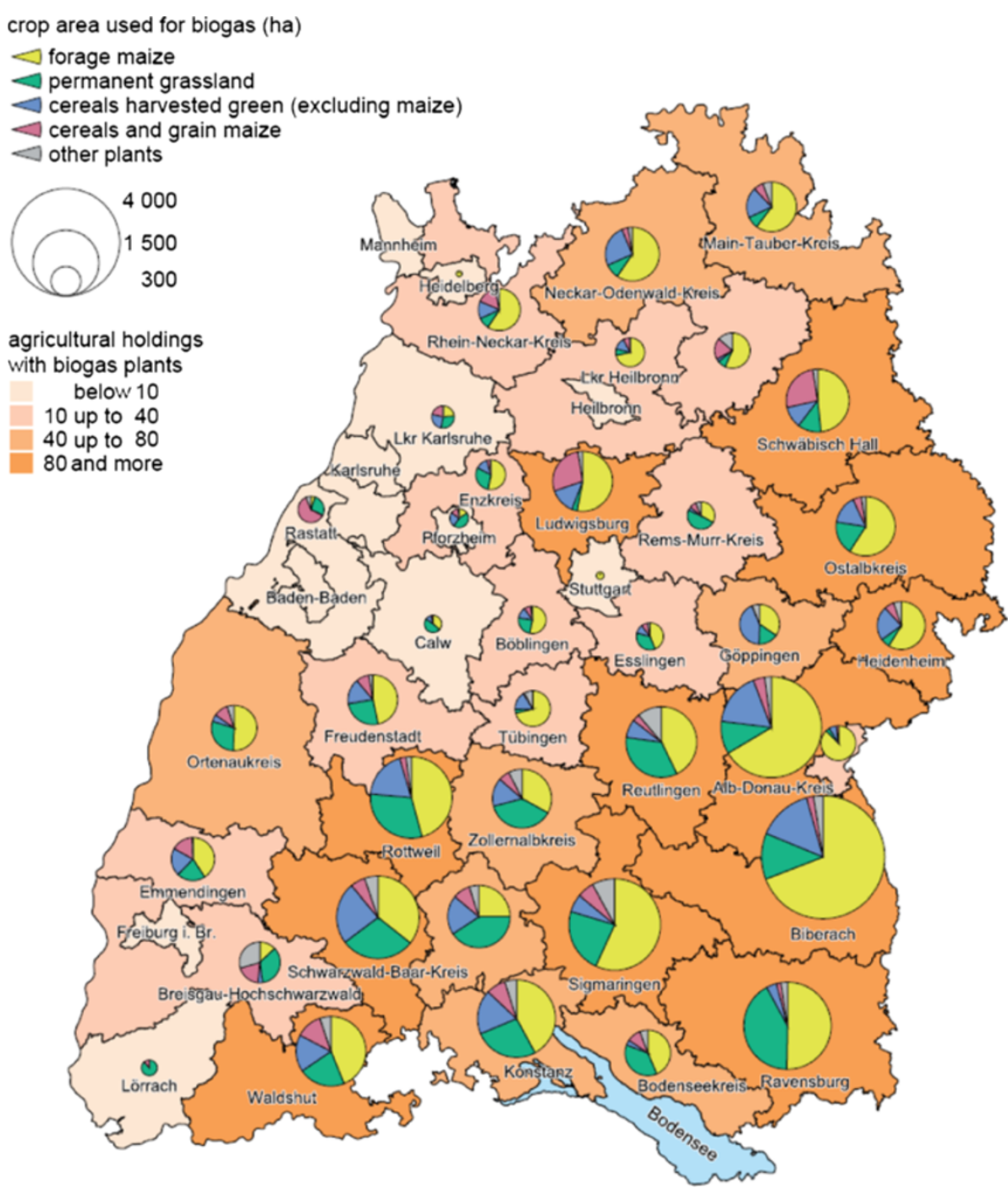

Figure 5 Grassland used for biogas production in the districts of Baden-Wuerttemberg [55].

transformed to SRC in a sustainable manner. Even if these restrictions are taken seriously, there are considerable areas of grassland available for the establishment of SRC as turn outs by the application of the sustainability principles in the state of Baden-Wuerttemberg.

The impacts on the cultural landscape heritage and nature's cultural functions, respectively, with regard to tourism and recreation are also crucial for assessing the sustainability and also the acceptability of land use change. Empirical surveys are needed to investigate the perception of land use changes from grassland to SRC on the levels of individuals, stakeholders, main actors and politicians, and group modelling is required to learn about the arguments and feelings behind the willingness for or resistance against land use change. In doing so, the preference of rejection of SRC has to be raised in comparison to other land use change for decentralized biomass and energy production technologies like open space photovoltaic or wind power. However, this would have been beyond the scope of this work. From lessons learned about land use change due to biogas plants and their demand of feedstock, it can be assumed that in particular large-scale SRC plantations could disrupt the character of the landscape and lead to the denegation of SRC. Hence, it will be of great importance to design and implement SRC in a way that the cultural and recreational landscape as well as human landscape perception, cognition and values are not affected negatively.

Regardless of the potential for sustainable land use change from grassland to SRC, the legislation in the state of Baden-Wuerttemberg prohibits the conversion of grassland at all. This regulation is a reaction to the conversion of grassland into arable land which begins with tillage, a practice known as negatively affecting soil properties and 


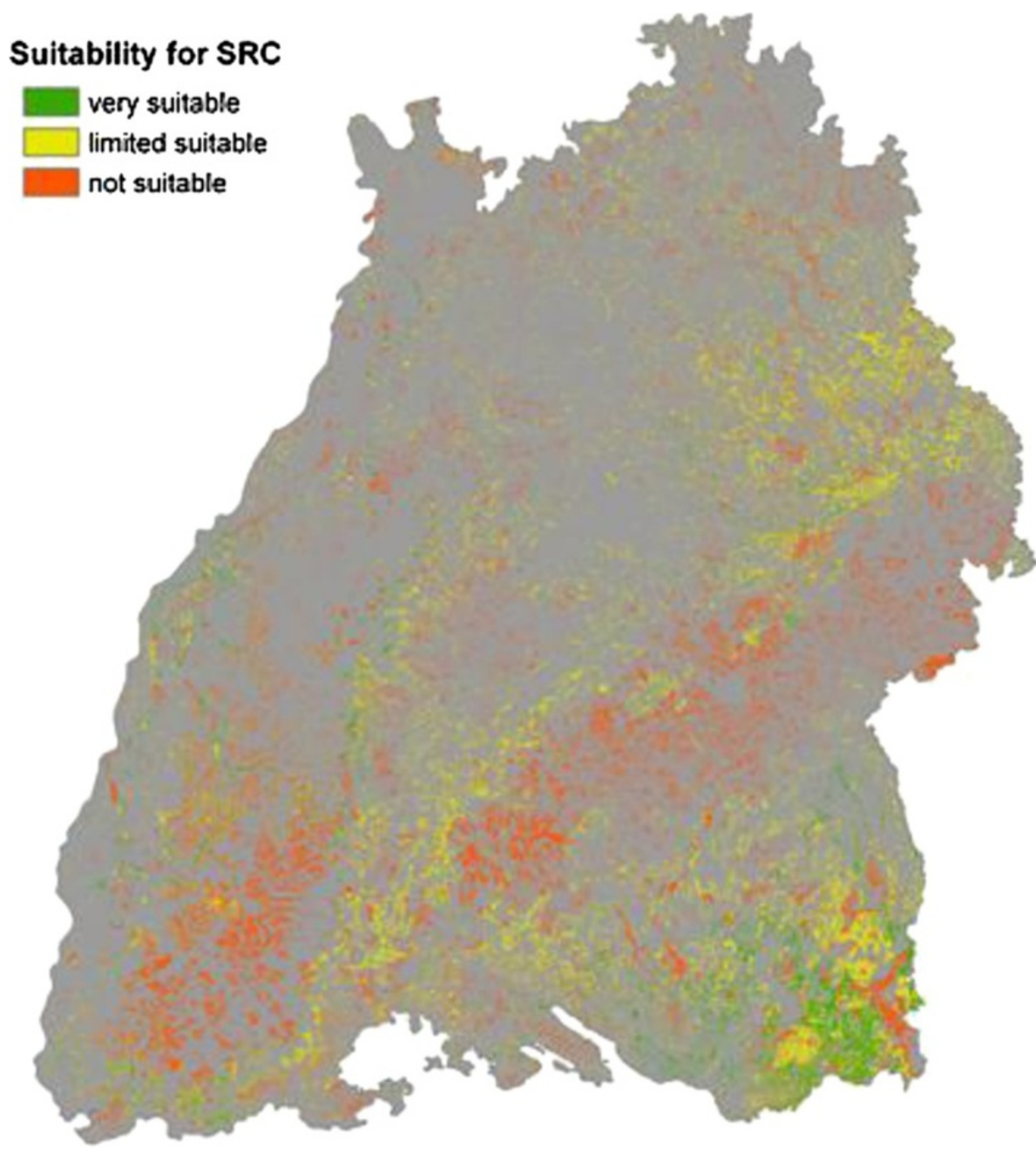

Figure 6 Suitability of grassland for the cultivation of SRC in Baden-Wuerttemberg with regard to sustainability criteria.

ecosystem processes in grassland-dominated ecosystems and to contributing to climate change by releasing soilbound carbon stocks. On the EU level, the conversion of grassland is prohibited also but so far this rule is only applicable for land with high carbon stocks and high biodiversity which will be used afterwards for biofuel production according to the EU Renewable Energy Directive. These regulations are designed mainly for the protection of biodiversity; soil and climate provoke questions about the future of grassland which is and will be released from their traditional functions for roughage production and play no vital role for nature conservation purposes. An increase in the intensity of dairy farming and in biogas production as well as agricultural changes can lead to a continuing conversion of grassland, in cases when grassland is rented by other farms. Grassland without any production or nature conservation functions will no longer contribute to the farmer's income and the added value of the region but has to be maintained instead with public funds.
The ban on the change of grassland has not only consequences on local employment and income, but also on the decentralized supply and use of renewable and storable energy. Moreover, public funding of research on SRC in general and the development of methods to establish SRC are needed in a way that soil functions and carbon stocks are largely preserved. However, in other German states, such as the Saarland, the establishment of SRC even on grassland is subsidized by the government with up to 1,000 euros per hectare in order to combat climate change with local actions. The objective is to establish SRC on marginal land where competition from other crops is less severe, due to their lower economic return, and with less intensive cultivation systems closer to traditional forest management.

\section{Conclusions}

The potential for a sustainable change in the use of land from grassland to SRC in south-west of Germany is likely to be significant and can contribute to decentralized 
renewable energy supply, local employment, and income. The exploitation of this potential is currently hindered by the prohibition to transform grassland to other types of land use in Baden-Wuerttemberg. This decision is strongly influenced by ecological aspects and does not consider the chances provided by SRC as an attractive alternative for a more extensive farming type and as additional local source for added value in economic and ecological terms. It is recommended to protect grassland more stringently on ecologically sensitive sites and also to strengthen legal standards of nature and water protection, but with regard to the lost economic values, not to set grassland conservation as an area-wide imperative.

In recognition of the advantages of SRC for sustainable land use, continuous research and demonstration of SRC are needed for improving the knowledge about site suitability and yields under current and future climates and frame conditions. Currently, only limited information is available for understanding the bottom-up spatial constraints for SRC production and both the changes in carbon stocks and the release of greenhouse gases, which are strongly dependent on the location, and the procedure how to establish SRC on grassland. More research is also required on supply chains to comprehend how demand and resource location affect costs and uptake in different end uses, and therefore inform on infrastructure and technologies that will be required.

Wood is the main renewable energy source in Germany and the government has ambitious targets to further increase the provision of bioenergy. Although all energy crops contribute to energy and climate-related sustainability goals, SRC are more favourable than annual energy crops to reach the targets. Nevertheless, the area of SRC in Germany is still very small and only slowly rising. This is mainly due to economic constraints and the lack of competiveness because of lower profit and return on investment compared with traditional crops. New and better incentives are needed for the establishment of SRC. Besides, more differentiated subsidies strategies based on spatial land use considerations have to be developed in order to achieve a better direct land use change. To avoid repeating the mistakes which have been made with other subsidies for energy crops and to ensure that the public money is achieving overall profit, sustainability criteria should be applied to allocate the SRC in locations where they can contribute best to nature and society.

By applying these criteria in the state of BadenWuerttemberg in a spatially differentiated bottom-up assessment, it was found that around $13 \%$ of the grassland might be available for SRC. Further research is needed not only in order to specify this preliminary allocation process and to tap the identified potential, but also in order to clarify whether SRC should mainly be established on agricultural land which cannot be used in a highly productive way due to diverse local disadvantages such as along small rivers, very wet areas or small fields. Strategies and measures need to be developed and implemented to direct the establishment of SRC to the most suitable areas. Moreover, it is necessary to integrate stakeholders, main actors and the general public into the process of identifying areas for SRC. A major challenge will be to gain acceptance for the changes in landscape which will be evoked by establishing SRC, as they can lead to negative impact on the cultural and recreational functions of the landscape.

\section{Abbreviations}

EU: European Union; MW: Megawatt; SRC: Short rotation coppice.

\section{Competing interests}

The authors declare that they have no competing interests.

\section{Authors' contributions}

CR formulated the concept and drafted the manuscript. CA participated in the spatial potential assessment. J J contributed to the 'Methods' section. All authors have read and approved the final manuscript.

\section{Authors' information}

CR is Head of the Research Unit 'Sustainability and Environment' at the Institute for Technology Assessment and Systems Analysis (ITAS) at Karlsruhe Institute of Technology (KIT). She is engaged in investigations and examining land which can be used for biomass production for non-food purposes with regard to sustainability issues. CA is a doctoral student at the Forest Research Institute Baden-Württemberg. He is dealing with the assessment of national and regional biomass potential of short rotation coppice on agricultural land in Germany. JJ is a senior scientist in the Institute for Technology Assessment and Systems Analysis at KIT and involved in sustainability analysis on land use change.

\section{Author details}

${ }^{1}$ Institute for Technology Assessment and Systems Analysis (ITAS), Karlsruhe Institute of Technology (KIT), P.O. Box 3640, 76021 Karlsruhe, Germany.

${ }^{2}$ Federal Forest Research Institute Baden-Wuerttemberg (FVA), P.O. Box 708, 79007 Freiburg, Germany.

Received: 2 April 2013 Accepted: 2 April 2013

Published: 22 April 2013

\section{References}

1. Nitsch H, Osterburg B, Roggendorf W, Laggner B (2012) Cross compliance and the protection of grassland - illustrative analyses of land use transitions between permanent grassland and arable land in German regions. Land Use Policy 29(2):440-448

2. Rösch C, Skarka J, Raab K, Stelzer V (2009) Energy production from grassland Assessing the sustainability of different process chains under German conditions. Biomass Bioenergy 33:689-700

3. Hartman A (2012) Dauergrünland in Baden-Württemberg. Statistisches Monatsheft Baden-Württemberg 2(2012):33-37

4. Mantau U, Saal U, Prins K, Steierer F, Lidner M, Verkerk H, Eggers J, Leek N, Odlenbuerger J, Asikainen A, Anttila P (2010) EUwood - real potential for changes in growth and use of EU forests. Final report, Hamburg, Germany, p 160

5. Fritsche UR, Dehoust $G$, Jenseit W, Hünecke $K$, Rausch L, Schüler D, Wiegmann K, Heinz A, Hiebel M, Ising M, Kabasci S, Unger C, Thrän D, Fröhlich N, Scholwin F, Reinhardt G, Gärtner S, Patyk A, Baur F, Bemmann U, Groß B, Heib M, Ziegler C, Flake M, Schmehl M, Simon S (2004) Stoffstromanalyse zur nachhaltigen energetischen Nutzung von Biomasse. Endbericht, Öko-Institut Darmstadt

6. Nitsch H, Osterburg B (2010) Grünland - Bestandsaufnahme und Handlungsoptionen: Erkenntnisse aus dem InVeKoS-Projekt. Experten Workshop Einsatz von Grünlandaufwuchs und Landschaftspflegematerial in. Biogasanlagen, Jena

7. EEA (European Environment Agency) (2007) Estimating the environmentally compatible bioenergy potential from agriculture, European Environment 
Agency. Technical report No 12/2007. Available at http://www.eea.europa. eu/publications/technical_report_2007_12 Accessed 12 Dec 2012

8. Kopfmüller J, Brandl V, Jörissen J, Paetau M, Banse G, Coenen R, Grunwald A (2001) Nachhaltige Entwicklung integrativ betrachtet. Konstitutive Elemente, Regeln, Indikatoren, Berlin

9. Kopfmüller J (2006) Ein Konzept auf dem Prüfstand. Das integrative Nachhaltigkeitskonzept in der Forschungspraxis. Edition Sigma, Berlin

10. Alexandratos N, Bruinsma J (2012) World agriculture towards 2030/2050, ESA working paper no. 12-03. Agricultural Development Economics Division of the Food and Agriculture Organization of the United Nations. Available at http://www.fao.org/docrep/016/ap106e/ap106e.pdf

11. DBV (Deutscher Bauernverband) (2012) Situationsbericht 2012/13. Trends und Fakten zur Landwirtschaft. Available at http://www.bauernverband.de/ situationsbericht-2013. Accessed 12 Dec 2012

12. Osterburg B, Laggner B, Nitsch H, Röder N, Roggendorf W (2010) Analysis of grassland conversion into arable land in Northwest Germany. Available at http://www.egf2011.at/files/pubs/350_osterburg.pdf. Accessed 12 Dec 2012

13. Osterburg B, Isermeyer F, Lassen B, Röder N (2010) Impact of economic and political drivers on grassland use in the EU. Grassland Sci Europe 15:14-28

14. LEL (Infodienst Landwirtschaft-Ernährung-Ländlicher Raum, Schwäbisch Gmünd) (2012) Agrarmärkte 2011/12 Milch. Available at http:// landwirtschaft-bw.de/pb/MLR.Landwirtschaft,Lde/Startseite/ Marktinformationen/Milch+_+Milchprodukte. Accessed 12 Dec 2012

15. The Federal Government (2008) Progress Report 2008 on the National Strategy for Sustainable Development. For a Sustainable Germany. Available at http://www.bundesregierung.de/Content/EN/_Anlagen/2009-05-13fortschrittsbericht-englisch-nachhaltigkeit.pdf?_blob=publicationFile

16. Bemmann A, Feger KH, Gerold D, Grosse W, Hartmann KU, Petzold R, Röhle H, Schweinle J, Steinke C (2007) Kurzumtriebsplantagen auf landwirtschaftlichen Flächen in der Region Grossenhain im Freistaat Sachsen. Forstarchiv 78(2007):95-101

17. Wagner P, Heinrich J, Kröber M, Schweinle J, Grosse W (2009) Ökonomische Bewertung von Kurzumtriebsplantagen und Einordnung der Holzerzeugung in die Anbaustruktur landwirtschaftlicher Unternehmen. In: Reeg T, Bemmann A, Konold W, Murach D, Spiecker H (ed) Anbau und Nutzung von Bäumen auf landwirtschaftlichen Flächen. Weinheim, Wiley-VCH Verlag, pp 135-145

18. Musshoff $O$ (2012) Growing short rotation coppice on agricultural land in Germany: a real options approach. Biomass Bioenergy 41:73-85

19. Stoate C, Baldi A, Beja P, Boatman ND, Herzon I, von Doorn A, de Snoo GR, Rakosy L, Ramwell C (2009) Ecological impacts of early 21st century agricultural change in Europe - a review. J Environ Manage 91(2009):22-46

20. Kleijn D, Kohler F, Baldi A, Batary P, Conception ED, Clough Y, DM Gabriel D, Holzschuh A, Knop E, Kovacs A, Marshall EJP, Tscharntke T, Verhulst J (2009) On the relationship between farmland biodiversity and land-use intensity in Europe. Proceedings of the Royal Society 276:903-990

21. Robert T, Watson R, Noble I, Bert Bolin NH, Ravindranath, David J, Verardo, Dokken David J (2000) Land use, land-use change and forestry. Cambridge University Press, Cambridge, p 375

22. Freibauer A, Drösler M, Gensior A, Schulze ED (2009) Das potenzial von wäldern und mooren für den klimaschutz in deutschland und auf globaler ebene. Natur und Landschaft 84(1):20-25

23. Lal R (2008) Carbon sequestration. Philos Trans R Soc B 363(2008):815-830

24. Guo LB, Gifford RM (2002) Soil carbon stocks and land use change: a meta analysis. Glob Chang Biol 8:345-360

25. Schlesinger WH (1997) Biogeochemistry: an analysis of global change. Academic, San Diego

26. Peters W, Schultze C (2010) Bioenergie und Naturschutz. Synergien fördern, Risiken vermeiden. Bonn, Bundesamt für Naturschutz (BfN). Available at http://www.bfn.de/fileadmin/MDB/documents/themen/ erneuerbareenergien/bfn_position_bioenergie_naturschutz.pdf

27. BUND (Bund für Umwelt und Naturschutz Deutschland) (2010) Kurzumtriebsplantagen für die Energieholzgewinnung - Chancen und Risiken. Positionspapier. Available at http://www.bund.net/fileadmin/ bundnet/publikationen/landwirtschaft/ 20100714_landwirtschaft_bund_position_55_KUP.pdf

28. NABU (Naturschutzbund Deutschland) (2008) Energieholzproduktion in der Landwirtschaft. Chancen und Risiken aus Sicht des Natur- und Umweltschutz. Available at http://www.nabu.de/imperia/md/content/ nabude/energie/biomasse/nabu-studie_energieholz.pdf
29. SRU (Sachverständigenrat für Umweltfragen) (2007) Klimaschutz durch Biomasse. Sondergutachten, Stuttgart. Available at http://www.umweltrat. de/cae/servlet/contentblob/467474/publicationFile/34339/ 2007_SG_Biomasse_Buch.pdf

30. Ledin S (1998) Environmental consequences when growing short rotation forests in Sweden. Biomass Bioenergy 15:49-55

31. Ranney JW, Mann LK (1994) Environmental considerations in energy crop production. Biomass Bioenergy 6:211-228

32. Sage RB, Cunningham M, Boatman N (2006) Birds in willow short-rotation coppice compared to other arable crops in central England and a review of bird census data from energy crops in the UK. Ibis. 148:184-197

33. Rossi A (2012) Good environmental practices in bioenergy feedstock production. Making bioenergy work for climate and food security. Environment and Natural Resources management Working Papers 49. Available at http://www.fao.org/docrep/015/i2596e/i2596e00.pdf

34. Pellegrino E, Di Bene C, Tozzini C, Bonari E (2011) Impact on soil quality of a 10-year-old short-rotation coppice poplar stand compared with intensive agricultural and uncultivated systems in a Mediterranean area. Agric Ecosyst Environ 140(1-2):245-254

35. Fry DA, Slater FM (2011) Early rotation short rotation willow coppice as a winter food resource for birds. Biomass Bioenergy 35(7):2545-2553

36. Goransson G (1994) Bird fauna of cultivated energy shrub forests at different heights. Biomass Bioenergy 6:49-52

37. Berg A (2002) Breeding birds in short-rotation coppices on farmland in central Sweden-the importance of Salix height and adjacent habitats. Agri Ecosyst and Env 90:265-276

38. Sage RB, Tucker K (1997) Invertebrates in the canopy of willow and poplar short rotation coppices. Aspects Appl Biol 49:105-111

39. Sage RB (1998) Short rotation coppice for energy: towards ecological guidelines. Biomass Bioenergy 15(1):39-47

40. Lettens S, Muys B, Ceulemans R, Moons E, Garcia J, Coppin P (2003) Energy budget and greenhouse gas balance evaluation of sustainable coppice systems for electricity production. Biomass Bioenergy 24(3):179-197

41. Matthews R, Robinson R, Abbott A, Fearis N (1994) Modelling of carbon and energy budgets of wood fuel coppice systems. Technical Report ETSU B/ W5/00337/REP, Mensuration Branch, Forestry Commission, for the Energy Technology Support Unit. Department of Trade and Industry, London, UK

42. Dubuisson X, Sintzoff I (1998) Energy and $\mathrm{CO}_{2}$ balances in different power generation routes using wood fuel from short rotation coppice. Biomass Bioenergy 15(4-5):379-390

43. DBFZ (Deutsches BiomasseForschungsZentrum (2011) Monitoring zur Wirkung des ErneuerbareEnergien-Gesetz (EEG) auf die Entwicklung der Stromerzeugung aus Biomasse. Zwischenbericht März 2011. Available at http://www.dbfz.de/web/fileadmin/user_upload/Userupload_Neu/ Stromerzeugung_aus_Biomasse_Zwischenbericht_Maerz_2011.pdf

44. Bell S, McIntosh E (2001) Short rotation coppice in the landscape. Guideline note from the Forestry Commission of Edinburgh. , UK. Available at http:// www.forestry.gov.uk/PDF/fcgn2.pdf/\$FILE/fcgn2.pdf

45. Petzold R, Feger KH, Siemer B (16/2006) Standörtliche Potenziale für den Anbau schnellwachsender Baumarten auf Ackerflächen. Allg. Forst. Z Waldwirtsch. Umweltvorsorge 16/2006:855-857

46. Murach D, Hartmann H, Walotek P (2008) Ertragsmodelle für landwirtschaftliche Dendromasse. Endbericht DENDROM - Zukunftsrohstoff Dendromasse. Ebers-walde, Berlin, Cottbus, pp 146-149

47. Aust C (2012) Abschätzung der nationalen und regionalen Biomassepotentiale von Kurzumtriebsplantagen auf landwirtschaftlichen Flächen in Deutschland, Dissertation an der Fakultät für. Universität Freiburg, Forst- und Umweltwissenschaften

48. Seitz R (2010) Rinderhaltung in Baden-Wuerttemberg. Statistisches Monatsheft Baden-Wuerttemberg :30-35

49. Rösch C, Raab K, Stelzer V (2005) Surplus grassland - a new source of bioenergy? In: Proceedings of the 14th European biomass conference \& exhibition. Frankreich, Paris, pp 312-315. CD-ROM

50. Landwirtschafts- und Landeskulturgesetz Baden-Württemberg Novellierung vom 17.12.2011. Available at http://www.landesrecht-bw.de/jportal/? quelle=jlink\&query=Lw\%2FKultG+BW\&psml=bsbawueprod. psml\&max=true\&aiz=true

51. Ministerrat der Europäischen Union (1992) Richtlinie/92/43/EWG vom 21. Mai 1992 zur Erhaltung der natürlichen Lebensräume sowie der wildlebenden Tiere und Pflanzen. Available at http://eur-lex.europa.eu/ LexUriServ/LexUriServ.do?uri=CONSLEG:1992L0043:20070101:DE:PDF 
52. Oppermann R (2009) Grünland und Schutz von Biodiversität und Gewässern. Vortrag auf der Tagung 'Naturschutz und Landwirtschaft im Dialog - Grünland im Umbruch' am 27.-30.04.2009 an der Internationalen Naturschutzakademie Insel Vilm des Bundesamtes für Naturschutz

53. Richtlinie des Ministeriums Ländlicher Raum zur Förderung der Erhaltung und Pflege der Kulturlandschaft und von Erzeugungspraktiken, die der Marktentlastung dienen (Marktentlastungs- und Kulturlandschaftsausgleich MEKA II -) vom 12.09.2000. Available at http://www.vd-bw.de/spiderlink/ 7803-3-1-3alt0708_02.B_inhalt

54. Tonn B, Messner J, Elsässer M (2010) Einsatz von (MEKA-)

Grünlandaufwüchsen in Biogasanlagen in Baden-Württemberg, Talk on Expert Workshop. Einsatz von Grünlandaufwuchs und Landschaftspflegematerial in Biogasanlagen, Jena. Available at http://www. tll.de/ainfo/pdf/gland/gn10_06f.pdf

55. Hartmann A (2008) Wie viel Fläche wird für Biogas benötigt? Statistisches Monatsheft Baden-Württemberg 7/2008, pp 40-42

56. Gömann H, Kreins P, Münch J, Delzeit R (2010) Auswirkungen der Novellierung des Erneuerbare-Energien-Gesetzes auf die Landwirtschaft in Deutschland, talk on the GEWISOLA meeting. Möglichkeiten und Grenzen der wissenschaftlichen Politikanalyse, 29.09-01.10. Braunschweig

57. Breustedt G, Habermann H (2010) Einfluss der Biogaserzeugung auf Landwirtschaftliche Pachtpreise. talk on the GEWISOLA meeting. Möglichkeiten und Grenzen der wissenschaftlichen Politikanalyse. Braunschweig

58. Statistisches Landesamt Baden-Württemberg (2010) Milcherzeugung und Milchverwendung in Baden-Württemberg. Available at http://www.statistik. baden-wuerttemberg.de/veroeffent//Statistische_Berichte/3432_10001.pdf

doi:10.1186/2192-0567-3-7

Cite this article as: Rösch et al: Envisioning the sustainability of the production of short rotation coppice on grassland. Energy, Sustainability and Society 2013 3:7.

\section{Submit your manuscript to a SpringerOpen ${ }^{\circ}$ journal and benefit from:}

- Convenient online submission

- Rigorous peer review

- Immediate publication on acceptance

- Open access: articles freely available online

- High visibility within the field

- Retaining the copyright to your article

Submit your next manuscript at $\gg$ springeropen.com 